\title{
Basque Language
}

National Cancer Institute

\section{Source}

National Cancer Institute. Basque Language. NCI Thesaurus. Code C153911.

A language isolate spoken in the Basque country of Spain and France. Basque is

unrelated to the other languages of Europe or to any other known living language. 